\title{
Insulin-like Effects of Vanadate on Rat Liver 6-Phosphofructo-2-Kinase/Fructose-2,6-Bisphosphatase mRNA and Protein Inductions in Diabetic Rats
}

\author{
Hiroshi INOUE, KoHeI KAKU, Akira MATSUTANI, \\ Tsuyoshi TAO, Hideo AYAME and Toshio KANEKO \\ The 3 rd Department of Medicine, Yamaguchi University \\ School of Medicine, Ube 755, Japan
}

\begin{abstract}
Effects of vanadate on liver 6-phosphofructo-2-kinase/fructose-2,6-bisphosphatase (6PF-2-K/ F-2,6- $\mathrm{P}_{2}$ ase) mRNA and protein inductions were examined in streptozotocin (STZ)-induced diabetic rats. In diabetic rats at one week after STZ (60 mg/ $\mathrm{kg}$ body weight), the liver $6 \mathrm{PF}-2-\mathrm{K}$ activity was decreased to $22 \%$ of the control. The enzyme protein was also decreased to $31 \%$ of the control, but the reduction in mRNA was not significant. Treatment of diabetes with vanadate $(10 \mathrm{mg} / \mathrm{kg} \mathrm{BW,} \mathrm{i.v.,}$ every $8 \mathrm{~h}$ ), as well as insulin (10 u/kg BW, s.c., every $8 \mathrm{~h}$ ), increased the 6PF-2-K activity and the enzyme protein content, though it was not completely restored to the control level. $68 \%$ of the control was the figure for enzyme activity and $65 \%$ of the control for protein content after 24-h of treatment. On the other hand, vanadate, like insulin, increased enzyme mRNA content to a higher level than the control ( $140 \%$ of the control). The present results indicate that vanadate, like insulin, modulates the liver 6PF-2-K/Fru-2,6- $\mathrm{P}_{2}$ ase gene expression, and stimulated protein induction contributes to the regulation of its enzyme activity, resulting in amelioration of the deranged carbohydrate metabolism in the diabetic state.
\end{abstract}

Key words: Vanadate, Insulin, 6PF-2-K/Fru-2,6- $\mathrm{P}_{2}$ ase mRNA, STZ-diabetic rat.

(Endocrine Journal 41: 75-82, 1994)

\begin{abstract}
VANADATE is an essential trace element in most mammalian tissues, but its function in cellular regulation and as an endogenous constituent is not well defined [1, 2]. Lines of evidence have revealed that vanadate has insulin-like effects on glucose metabolism both in vivo and in vitro. Among these effects are the stimulation of glucose transport and glucose utilization in adipocytes [3-5] and muscle $[6,7]$, and the activation of glycogen synthesis in adipocytes [4, 5] and hepatocytes [8]. Vanadate treatment normalized blood glucose levels and prevented depression of cardiac performance in diabetic rats [9]. Furthermore, vanadate stimulated

Received: September 6, 1993

Accepted: November 19, 1993

Correspondence to: Dr. Kohei KAKU, The 3rd Department of Medicine, Yamaguchi University School of Medicine, 1144 Kogushi, Ube 755, Japan
\end{abstract}

liver fructose-2,6-bisphosphate (Fru-2,6- $\mathrm{P}_{2}$ ) production and glucokinase activity, and insulinregulable muscle glucose transporter gene expression which were decreased in streptozotocin-induced diabetic rats $[7,8,10-12]$. Thus, studies of vanadate action have led to numerous insights into cellular metabolism and to the examination of a variety of hypotheses with respect to insulin action.

Liver fructose-2,6-bisphosphate (Fru-2,6- $\mathrm{P}_{2}$ ) is known to be the most potent activator of 6phosphofructo-1-kinase, a rate limiting enzyme of glycolysis, and an inhibitor of fructose-1,6bisphosphatase [12, 13]. The Fru-2,6- $\mathrm{P}_{2}$ level is regulated by a bifunctional enzyme, 6phosphofructo-2-kinase / fructose-2,6-bisphosphatase (6PF-2-K/Fru-2,6- $\mathrm{P}_{2}$ ase). This enzyme activity is regulated by several allosteric effectors 
and covalent modification through phosphorylation, mainly catalyzed by cyclic AMP dependent protein kinase (A-kinase) [14, 15]. Insulin is proposed to inhibit A-kinase dependent phosphorylation of the enzyme protein, increasing the 6PF-2-K activity in an acute manner [16]. On the other hand, recent reports demonstrated that starvation or diabetes decreased liver Fru-2,6- $\mathrm{P}_{2}$ and 6PF-2$\mathrm{K} /$ Fru-2,6- $\mathrm{P}_{2}$ ase protein, but not mRNA [17, 18]. A significant increase in enzyme protein and mRNA for $6 \mathrm{PF}-2-\mathrm{K} / \mathrm{Fru}-2,6-\mathrm{P}_{2}$ ase with refeeding and insulin treatment suggested an insulin-dependent stimulation of the enzyme gene expression [17].

Recent studies revealed that the liver $6 \mathrm{PF}-2-\mathrm{K}$ and Fru-2,6- $\mathrm{P}_{2}$ ase activities were regulated by vanadate $[10,11,19,20]$. A recent study by us also demonstrated that vanadate increased the $6 \mathrm{PF}-2-\mathrm{K}$ activity in isolated rat hepatocytes, resulting in the stimulation of Fru-2,6- $\mathrm{P}_{2}$ production (unpublished data). However, the precise mechanism of the effect of vanadate on this enzyme activity had remained to be clarified. In the present study, to characterize the mechanism of vanadate action on the regulation of the bifunctional enzyme activity, we examined whether or not vanadate regulates the liver $6 \mathrm{PF}-2-\mathrm{K} /$ Fru-2,6- $\mathrm{P}_{2}$ ase mRNA and protein inductions. For this purpose, we investigated the effects of vanadate in the diabetic state in streptozotocin (STZ)-induced diabetic rats, and compared them with those of insulin. Here, we reported the stimulatory effect of vanadate, like insulin, on the bifunctional enzyme mRNA and protein inductions.

\section{Materials and Methods}

\section{Chemicals}

Pyrophosphate-dependent phosphofructokinase (PPi-PFK), fructose-2,6-bisphosphate (Fru-2,6- $\mathrm{P}_{2}$ ) and streptozotocin (STZ) were purchased from Sigma Co. (St. Louis, MO). Human Actrapid insulin was a product of Novo-Nordisk (Gentofte, Denmark). Sodium orthovanadate $\left(\mathrm{Na}_{3} \mathrm{VO}_{4}\right)$ was obtained from Nacalai Tesque lnc. (Kyoto, Japan). A cDNA for rat liver $6 \mathrm{PF}-2-\mathrm{K} / \mathrm{Fru}-2,6-\mathrm{P}_{2}$ ase $\left(2^{k 1400}\right)$ was a kind gift from Dr. S. J. Pilkis [21]. [ $\alpha-$ $\left.{ }^{32} \mathrm{P}\right] \mathrm{dCTP}$, a multiprime DNA labeling kit and ECL western blotting detection system were purchased from Amersham Japan Corp. (Tokyo, Japan).
NADH, fructose-6-phosphate (Fru-6-P), glycerin-3phosphate dehydrogenase,triosephosphate isomerase and aldose were products of Boehringer Manheim (Germany). All other reagents were of analytical grade.

\section{Treatment of Animals}

Male Wistar rats weighing 200-250 g were made diabetic by intravenous injections of freshly prepared STZ (60 mg/ $\mathrm{kg}$ body weight) dissolved in $0.2 \mathrm{ml}$ of $0.1 \mathrm{M}$ citrate buffer, $\mathrm{pH}$ 4.5. Controls received buffer injections only. Blood glucose levels were determined one week after STZ injection. Animals with blood glucose concentrations exceeding $22 \mathrm{mmol} / \mathrm{l}$ were included in the study. At one week after the STZ-treatment, the animals were randomly divided into four groups: normal controls, untreated diabetic animals, insulintreated animals and vanadate-treated animals. The insulin- or vanadate-treated animals received $10 \mathrm{unit} / \mathrm{kg}$ body weight of Actrapid insulin or 10 $\mathrm{mg} / \mathrm{kg}$ body weight of sodium orthovanadate dissolved in $80 \mathrm{mM} \mathrm{NaCl}$ subcutaneously every $8 \mathrm{~h}$. Insulin or vanadate administration was started at $0800 \mathrm{~h}$ in the morning and was continued for $48 \mathrm{~h}$. Normal control and untreated diabetic rats only received $80 \mathrm{mM} \mathrm{NaCl}$ every $8 \mathrm{~h}$. All animals were given a standard laboratory chow and tap water ad libitum throughout the experiments. Rats were sacrificed at the time indicated during the treatment with insulin, vanadate, or $\mathrm{NaCl}$ solution for $48 \mathrm{~h}$. Blood samples were collected at the time of death. The livers were removed and immediately frozen in liquid nitrogen.

\section{Assay of liver 6PF-2-K activity}

Liver blocks were homogenized with a polytron homogenizer in $50 \mathrm{mM}$ Tris, $\mathrm{pH}$ 8.0, $0.2 \mathrm{mM}$ ATP, $0.2 \mathrm{mM}$ EDTA, $1 \mathrm{mM}$ DTT, and 1\% PEG300. The homogenates were centrifuged at $105,000 \times \mathrm{g}$ for $40 \mathrm{~min}$ at $4^{\circ} \mathrm{C}$. The $6 \mathrm{PF}-2-\mathrm{K}$ activity was measured by a modification of the method described previously [15]. The reaction mixture consisted of 20 $\mathrm{mM}$ HEPES, pH 7.4, with $10 \mathrm{mM} \mathrm{MgCl}_{2}, 1 \mathrm{mM}$ EGTA, $1 \mathrm{mM}$ DTT, $5 \mathrm{mM}$ ATP, $1 \mathrm{mM}$ Fru-6-P, and $10 \mu l$ of the supernatant of the liver homogenate in a total volume of $100 \mu l$. After incubation for 20 min at $37^{\circ} \mathrm{C}$, the reaction was terminated by the 
addition of $25 \mu l$ of $0.5 \mathrm{~N} \mathrm{NaOH}$, and immediately applied to the Fru-2,6- $\mathrm{P}_{2}$ assay system. The amount of Fru-2,6- $\mathrm{P}_{2}$ produced was determined by the modified method of El-Maghrabi et al. [22].

\section{Northern and dot blot analyses}

Total RNA was purified from a frozen liver sample according to the previously described technique [23]. The RNA ( $20 \mu \mathrm{g})$ was denatured, separated on $1 \%$ agarose formaldehyde gel and blotted on Zeta-Probe nylon membrane (Bio-Rad Laboratories, Richmond, CA). For dot blot analysis, denatured RNA samples were applied to a nylon membrane with a 96 well Hybri-dot apparatus (Bethesda Research Laboratories, Gaithersburg, $\mathrm{MD})$. After baking for $1 \mathrm{~h}$ at $80^{\circ} \mathrm{C}$, the filter was prehybridized for 2-3 $\mathrm{h}$, and hybridized with radioactive cDNA probe for $6 \mathrm{PF}-2-\mathrm{K}$ or $\beta$-actin in $5 \times$ SSPE, $50 \%$ formamide, $0.5 \%$ SDS, $0.1 \mathrm{mg} / \mathrm{ml}$ salmon sperm DNA, and $5 \times$ Denhardt's solution. Radioactive cDNA probes were made by means of the Multiprime Labeling System (Amersham Japan Corp., Tokyo). The filter was washed in $1 \times$ SSC, $0.5 \%$ SDS 3 times for $5 \mathrm{~min}$ at room temperature and in $0.1 \times$ SSC, $0.5 \%$ SDS 3 times for $15 \mathrm{~min}$ at $50^{\circ} \mathrm{C}$, and then exposed to Kodak X-ray film with an intensifying screen for $12-24 \mathrm{~h}$ at $-80^{\circ} \mathrm{C}$. Quantification of bands or spots on the autoradiogram was done with a scanning densitometer.

Polyclonal antibody to the liver 6PF-2-K/Fru-2,6- $P_{2}$ ase

Polyclonal antibody to the liver 6PF-2-K/Fru2,6- $\mathrm{P}_{2}$ ase was prepared to use in western blot analysis. A peptide corresponding to C-terminal 15 amino-acid residues (456-470) of the enzyme was synthesized by the Merrifield solid-phase synthesis method [24]. The synthesized peptide was conjugated to keyhole limpet hemocyanin with glutaraldehyde, emulsified with complete Freund's adjuvant, and then injected subcutaneously into foot pads of male Japanese white rabbits. The injection was repeated every 2 weeks. The sera were monitored for specificity and the capacity to bind to the synthesized peptide and purified rat liver 6PF-2$\mathrm{K} / \mathrm{F}-2,6-\mathrm{P}_{2}$ ase in ELISA, and for the immunoprecipitation of 6PF-2-K activity.

\section{Western blot analysis}

After homogenizing the liver blocks as described above, $20 \mu \mathrm{g}$ of each sample were subjected to SDS-polyacrylamide gel ( $8 \%$ acrylamide). Proteins were transferred to a nitrocellulose membrane (Zeta-Probe; Bio-Rad Laboratories, Richmond, CA) by means of a Bio-Rad Transblotter with a transfer buffer consisting of $25 \mathrm{mM}$ Tris- $\mathrm{HCl}, \mathrm{pH} \mathrm{8.3,} 192$ $\mathrm{mM}$ glycine, $20 \%$ methanol. Membranes were washed with PBS-Tween buffer consisting of 10 $\mathrm{mM}$ PBS, $\mathrm{pH} 7.2$, and $0.05 \%$ polyoxyethyenesorbitan monolaurate (Tween 20) 3 times for 15 min each time. Excess sites on the membrane were saturated with $3 \%$ bovine serum albumin (BSA) in PBS buffer, $\mathrm{pH} 7.2$ at $4^{\circ} \mathrm{C}$ overnight. After washing the membrane with the PBS-Tween buffer, the membrane was incubated with the same buffer containing a 1:1000 dilution of antibody to 6PF-2$\mathrm{K} /$ Fru-2,6- $\mathrm{P}_{2}$ ase and $3 \% \mathrm{BSA}$ for $30 \mathrm{~min}$ at room temperature. The membrane was washed 3 times for 5 min each time with the PBS-Tween buffer, and then incubated with peroxidase-bound donkey anti-rabbit IgG in the PBS-Tween buffer for $2 \mathrm{~h}$ at room temperature. The membrane was washed 3 times for $10 \mathrm{~min}$ with the PBS-Tween buffer, and further incubated with $12 \mathrm{ml}$ of the detection buffer of an ECL Western detection kit (Amersham Japan Corp.) consisting of $10 \mathrm{mM}$ PBS, pH 7.5, 6 $\mathrm{mg}$ 4-chloro-1-naphtol, $0.012 \% \mathrm{H}_{2} \mathrm{O}_{2}$ and $20 \%$ methanol for approximately $15 \mathrm{~min}$ at room temperature. After washing the membrane, the chemiluminescence generated was exposed to X-ray film. Bands were quantified with a scanning densitometer (GS300, Hoefer Sci. Ins.)

\section{Other methods}

Blood glucose was measured with an autoanalyzer (YSI Model 23A, YSI Incorp., Japan). Plasma insulin was analyzed by a double-antibody radioimmunoassay (Shionogi RIA kit, Japan) with purified rat insulin standards (Novo, Copenhagen). Protein was measured by the method of Lowry et al. [25]. 


\section{Results}

\section{Blood glucose and plasma insulin levels}

The blood glucose level of diabetic rats at one week after STZ injection was markedly higher than that of control animals $(29.1 \pm 3.2$ and $9.3 \pm 0.5$ $\mathrm{mmol} / l$, mean $\pm \mathrm{SD}, \mathrm{n}=4, P<0.001)$. On the other hand, the plasma insulin concentration of diabetic rats was decreased to about $20 \%$ of the control ( 2.3 \pm 0.3 and $11.5 \pm 1.9 \mathrm{ng} / \mathrm{ml}, \mathrm{n}=4, P<0.001$ ). The administration of insulin induced a recovery from weight reduction and improved polyuria, and lowered the blood glucose concentration of diabetic rats although it was still higher than that of normal rats. Vanadate completely normalized the high blood glucose of diabetic rats within $24 \mathrm{~h}$, but the plasma insulin level was not altered (Table 1).

\section{Liver 6PF-2-K activity}

As shown in Fig. 1, the liver 6PF-2-K activity in diabetic rats at one week after STZ injection was decreased to $22 \%$ of the control $(30.5 \pm 5.3$ and 141 $\pm 13 \mathrm{pmol} / \mathrm{min} / \mathrm{mg}$ protein, $\mathrm{n}=5, P<0.001)$. Treatment of diabetes with insulin and vanadate increased the 6PF-2-K activity, though it was not completely restored to the control level. The 6PF-2$\mathrm{K}$ activity was increased to $101.5 \pm 7.5 \mathrm{pmol} / \mathrm{min} /$ $\mathrm{mg}$ protein ( $72 \%$ of the control) and $115 \pm 10.2$ $\mathrm{pmol} / \mathrm{min} / \mathrm{mg}$ protein ( $82 \%$ of the control) after a $24 \mathrm{~h}$ and a $48 \mathrm{~h}$ insulin treatment, respectively. Vanadate also increased the kinase activity to 95.8 \pm 18.5 (68\% of the control) after a $24 \mathrm{~h}$ treatment, and to $118 \pm 15.8 \mathrm{pmol} / \mathrm{min} / \mathrm{mg}$ protein $(84 \%$ of the control) after a $48 \mathrm{~h}$ treatment.

Table 1. Blood glucose and plasma insulin levels of the normal control and the diabetic rats

\begin{tabular}{lcc}
\hline & $\begin{array}{c}\text { Blood glucose } \\
(\mathrm{mmol} / \mathrm{l})\end{array}$ & $\begin{array}{c}\text { Plasma insulin } \\
(\mathrm{ng} / \mathrm{ml})\end{array}$ \\
\hline Control & $9.3 \pm 0.5$ & $11.5 \pm 1.9$ \\
Diabetic & & \\
$\quad$ untreated & $29.1 \pm 3.2^{*}$ & $2.3 \pm 0.3^{*}$ \\
$\quad$ insulin & $17.6 \pm 4.2^{*}$ & $10.8 \pm 3.5$ \\
$\quad$ vanadate & $9.2 \pm 1.4$ & $2.1 \pm 0.3^{*}$ \\
\hline
\end{tabular}

These levels were measured after 24 - $h$ treatment with saline (control and untreated), insulin or vanadate as described in the text. Each value indicates the mean $\pm \operatorname{SD}(n=4) .{ }^{*}, P<0.01$ vs. control.

\section{Liver 6PF-2-K/Fru-2,6-P ase mRNA level}

Fig. 2 shows the Northern analysis data for 6PF2-K/Fru-2,6- $\mathrm{P}_{2}$ ase mRNA of the liver obtained from the normal rats and diabetic rats treated with insulin or vanadate for $24 \mathrm{~h}$. The bifunctional enzyme mRNA appeared as a $2.2 \mathrm{~kb}$ band on a Northern blot. Treatment of diabetic rats with insulin and vanadate significantly increased the induction of 6PF-2-K mRNA to a rather higher level than the control. The liver 6PF-2-K mRNA levels were determined by dot blot analysis (Fig. 3). The mRNA level of the diabetic rat was not significantly different from that of the control. After treatment of diabetes with insulin and vanadate for $24 \mathrm{~h}$, the enzyme message amount increased to over $150 \%$ and $140 \%$ of the control level, respectively.

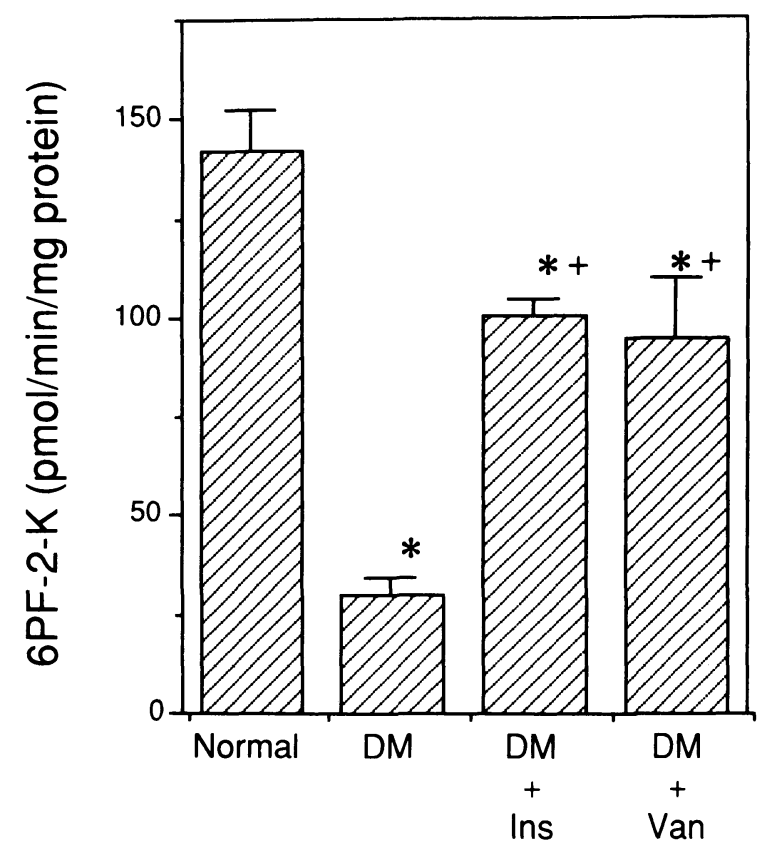

Fig. 1. Effects of diabetes (DM) and treatment with vanadate or insulin on rat liver 6-phosphofructo-2kinase $(6 \mathrm{PF}-2-\mathrm{K})$ activity. The liver samples were obtained from the normal, the untreated diabetic, or the diabetic rats treated with vanadate or insulin for $24 \mathrm{~h}$ as described in the text. The 6PF-2-K activity was measured as described in the text. Each value indicates the mean $\pm S D(n=5) .{ }^{*}, P<0.05$ vs. the normal control;,$+ P<0.05$ vs. the untreated diabetic. 


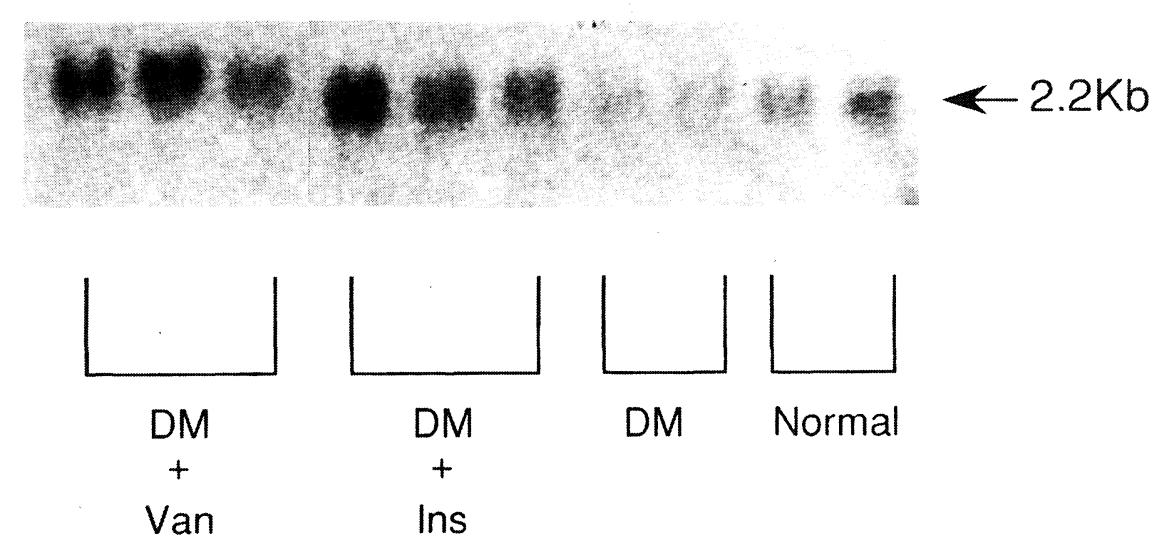

Fig. 2. Northern blot analysis of rat liver 6-phosphofructo-2-kinase/fructose-2,6bisphosphatase mRNA. The liver samples were obtained as described in the legend to Fig. 1. Shown is an autoradiogram of a Northern blot of rat liver total RNA, $20 \mu \mathrm{g}$ per lane, that was probed with $\left[{ }^{32} \mathrm{P}\right] \mathrm{CDNA}{ }^{2 \mathrm{k} 1400}$. Each lane indicates the mRNA from each individual animal.

\section{Liver 6 PF-2-K/Fru-2,6- $P_{2}$ ase protein level}

As shown in Fig. 4, liver 6PF-2-K/Fru-2,6- $\mathrm{P}_{2}$ ase protein was identified as a single band with a molecular weight of $55 \mathrm{kDa}$ by Western blot analysis. The enzyme protein concentration of diabetic rats was significantly lower than that of the control rats ( $31 \%$ of the control). Insulin restored the protein level to $67 \%$ of the normal control after a $24 \mathrm{~h}$ treatment and $79 \%$ of the control after a $48 \mathrm{~h}$ treatment. Vanadate also restored the protein level to $65 \%$ and $78 \%$ of the control after a $24 \mathrm{~h}$ and a $48 \mathrm{~h}$ treatment, respectively. Thus, the change in the enzyme protein level was well correlated with a change in the enzyme activity in each group of rats.

\section{Discussion}

Previous reports revealed that vanadate stimulated the liver 6PF-2-K activity and inhibited Fru2,6- $\mathrm{P}_{2}$ ase activity, resulting in an increase in Fru$2,6-\mathrm{P}_{2}$ content in vivo and in vitro [10, 11, 19, 20]. The mechanism of vanadate action on this enzyme activity, however, had not been clarified. Miralpeix et al. reported the effect of vanadate on a long term regulation of $6 \mathrm{PF}-2-\mathrm{K}$ activity and Fru-2,6- $\mathrm{P}_{2}$ level using primary cultured rat hepatocytes [19]. Insu- lin- and vanadate-stimulated enzyme activities were inhibited by cycloheximide, a specific blocker of protein synthesis at the translational level. Thus, they concluded that vanadate enhanced hepatocyte $6 \mathrm{PF}-2-\mathrm{K}$ activity as well as that of insulin, probably due to the induction of the enzyme protein rather than by a change in the catalytic activity.

The present study demonstrated for the first time that the liver $6 \mathrm{PF}-2-\mathrm{K} / \mathrm{Fru}-2,6-\mathrm{P}_{2}$ ase mRNA and protein levels in the STZ-diabetic rat were altered by the administration of vanadate. The present study also indicated that the enzyme protein content was well reflected in the enzyme activity. Thus, the present results, which revealed a significant correlation between the enzyme activity and its protein content, may confirm the hypothesis of Miralpeix et al. [19]. In the present study, the treatment of diabetes with vanadate lowered the blood glucose level, but did not alter the plasma insulin level. It is well known that glucose, like insulin, regulates hepatic 6PF-2-K/Fru-2,6$\mathrm{P}_{2}$ ase activity; a high concentration of glucose increased the hepatic Fru-2,6- $\mathrm{P}_{2}$ level in vivo and in vitro [12]. Therefore, in this study, it is unlikely that vanadate increased the $6 \mathrm{PF}-2-\mathrm{K}$ activity and the enzyme protein level by normalizing blood glucose. Whether vanadate directly exerts its effect to regulate hepatic $6 \mathrm{PF}-2-\mathrm{K} / \mathrm{Fru}-2,6-\mathrm{P}_{2}$ ase $\mathrm{mRNA}$ and 
protein levels or not, however, remains to be elucidated.

It has been reported that the liver 6PF-2-K activity and its gene expression are regulated by feeding, the diabetes state, and insulin treatment; the 6PF-2-K activity and its protein level were reduced in the diabetic state or starvation, but not the mRNA level [17, 18]. Similarly, the present study revealed that the liver $6 \mathrm{PF}-2-\mathrm{K} / \mathrm{Fru}-2,6-\mathrm{P}_{2}$ ase protein level decreased significantly, but not the mRNA level in the diabetic state. A recent study demonstrated that insulin stimulates the bifunc-
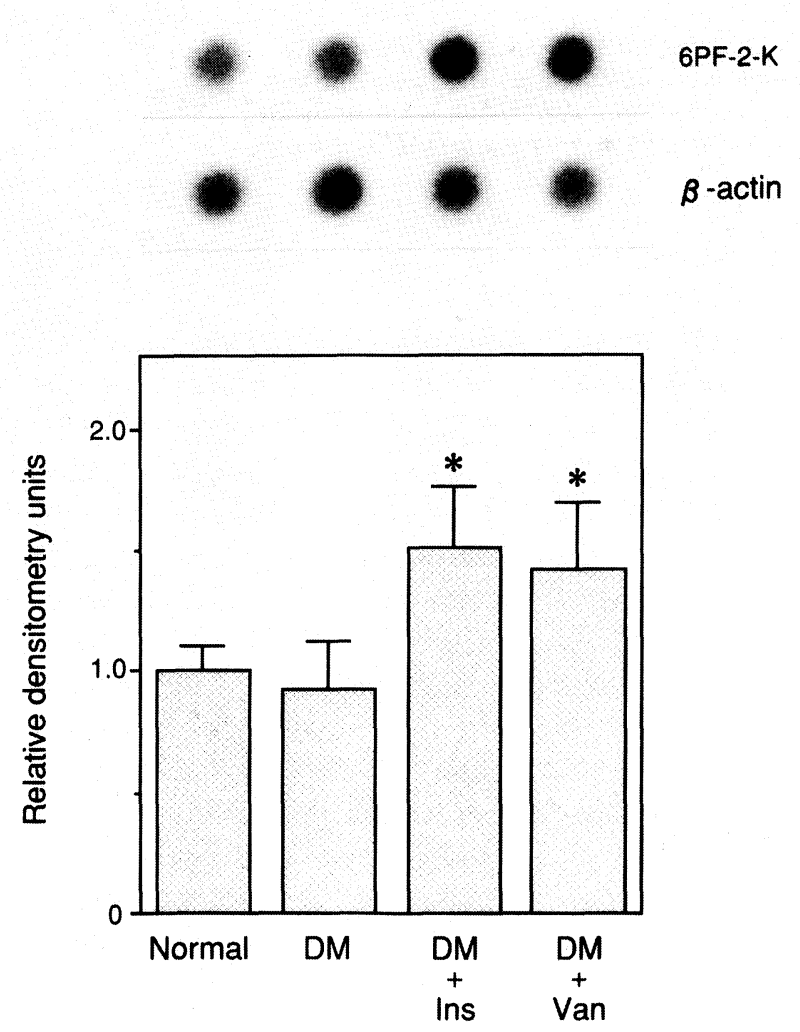

Fig. 3. Effects of diabetes and treatment with vanadate or insulin on rat liver 6-phosphofructo-2-kinase/ fructose-2,6-bisphosphatase mRNA. Dot blot analysis was carried out as described in the text. Normalization of the signal intensity generated from $\left[{ }^{32} \mathrm{P}\right] \mathrm{CDNA}{ }^{2 \mathrm{k} 1400}$ was achieved by rehybridizing with $\left.{ }^{32} \mathrm{P}\right] \mathrm{cDNA}{ }^{\beta \text {-actin }}$ as an internal control. Ratios of the enzyme to $\beta$-actin mRNA signal shown in the lower panel are expressed as arbitrary density units reflective of relative enzyme mRNA concentrations. Shown are relative ratios when the arbitrary density unit of the normal control is 1.0. Each value indicates the mean $\pm S D(n=4) .{ }^{*}, P<0.05$ vs. the normal control. tional enzyme gene transcription, but does not alter the rate of degradation of mRNA in rat hepatoma cells [26]. The treatment of diabetes with vanadate, like insulin, induced a significant increase in the bifunctional enzyme mRNA content. The increase in the mRNA content, however, did not reflect the increase in the protein level. Thus, these observations may mean that translational efficiency and/or protein stability are reduced in the diabetic state as noted in the previous reports $[17,18]$. The reduced enzyme protein content resulted in the decreased 6PF-2-K activity in diabetic rats.

The mechanism of the cellular action of vanadate is not fully understood although several hypotheses have been proposed. Vanadate stimulates the insulin receptor tyrosine kinase activity $[4,27,28]$. The post-receptor effects of vanadate have also been proposed [29, 30]. On the other hand, McNeill and his associates suggested that vanadate treatment may lead to some restoration of pancreatic function in STZ-diabetic rats [31]. In the next study on the long-term effectiveness of oral vanadyl sulphate in STZ-diabetic rats, however, they concluded that the significant amelioration of the diabetic state by vanadate treatment is induced by direct effects on the peripheral target tissues at the level of the insulin receptor or post-receptor events which are unrelated to protection from the acute toxic effects of STZ on pancreatic beta-cells [32]. The present study also did not reveal a significant increase in the serum insulin level. Our results may therefore support the concept that vanadate exerts its effect directly on the liver and is not dependent upon restored pancreatic beta-cell function. To elucidate the mechanisms of vanadate action in the diabetic state, further studies are required.

It is well known that liver $6 \mathrm{PF}-2-\mathrm{K} / \mathrm{Fru}-2,6-\mathrm{P}_{2}$ ase activity and Fru-2,6- $\mathrm{P}_{2}$ production are regulated by hormones, carbohydrates and sulfonylurea drugs $[12,13,33,34]$. This bifunctional enzyme activity is ruled by the phosphorylation state and the amount of the enzyme protein [14, 15, 17, 18]. Insulin is known to regulate both the phosphorylation state and the protein level of the liver 6PF-2-K/Fru-2,6$\mathrm{P}_{2}$ ase [16-18]. A recent study by us demonstrated that tolbutamide, a sulfonylurea drug, inhibits the bifunctional enzyme protein phosphorylation catalyzed by cAMP-dependent protein kinase, result- 


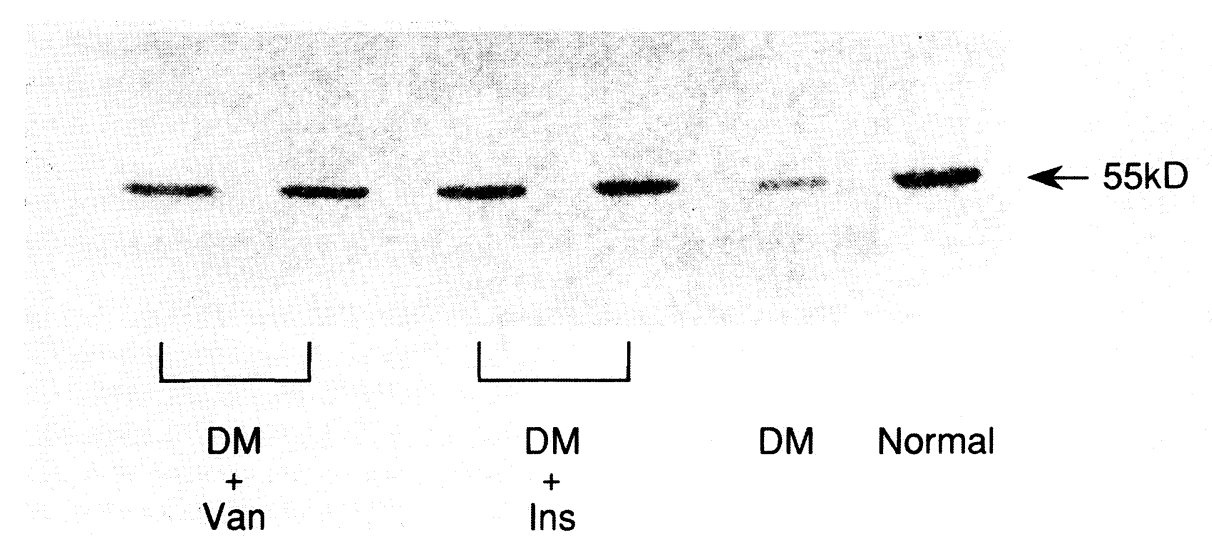

Fig. 4. Western blot analysis of rat liver 6-phosphofructo-2-kinase/fructose-2,6bisphosphatase protein after a $24-\mathrm{h}$ treatment with insulin or vanadate. The liver samples were obtained as described in the legend to Fig. 1. Western blot analysis was done as described in the text. Typical results for four separate experiments are shown.

ing in activation of $6 \mathrm{PF}-2-\mathrm{K}$ and inactivation of Fru-2,6- $\mathrm{P}_{2}$ ase [35]. The effect of vanadate on the phosphorylation of this bifunctional enzyme protein should be clarified in a future study. On the other hand, we demonstrated that vanadate exerts an additive effect on sulfonylurea-stimulated 6PF$2-\mathrm{K}$ activity and Fru-2,6- $\mathrm{P}_{2}$ production as well as insulin (unpublished data). This may mean that the mechanism of vanadate and insulin action on the bifunctional enzyme activity differs from that of sulfonylurea.

The results herein suggested that vanadate and insulin possess similar actions on liver $6 \mathrm{PF}-2-\mathrm{K}$ activity and enzyme mRNA and protein inductions although the precise mechanism of the vanadate effect is not yet clear. This information may provide a valuable insight into the mechanism of the antidiabetic action of insulin and vanadate. Further studies are required to clarify whether vanadate, like insulin, exerts its action on enzyme phosphorylation, since previous reports have suggested that vanadium compounds could mediate changes in the concentration of cAMP and $\mathrm{Ca}^{2+}$ ions [1, 2].

\section{References}

1. Nachay BR (1984) Mechanisms of action of vanadium. Ann Rev Pharmacol Toxicol 24: 501-524.

2. Ramasarma T, Crane FL (1981) Does vanadium play a role in cellular regulation? Curr Top Cell Regul 20: 247-301.

3. Shechter Y, Karlish SJD (1980) Insulin-like stimulation of glucose oxidation in rat adipocytes by vanadyl (IV) ions. Nature 284: 556-558.

4. Tamura S, Brown TA, Dubler RE, Larner J (1983) Insulin-like effect of vanadate on adipocyte glycogen synthase and on phosphorylation of 95,000 dalton subunit of insulin receptor. Biochem Biophys Res Commun 113: 80-86.

5. Tamura S, Brown TA, Whipple JH, FujitaYamaguchi Y, Dubler RE, Cheng K, Larner J (1984) A novel mechanism for the insulin-like effect of vanadate on glycogen synthesis in rat adipocytes. $J$
Biol Chem 259: 6650-6658.

6. Clark AS, Fagan JM, Mitch WE (1985) Selectivity of the insulin-like actions of vanadate on glucose and protein metabolism in skeletal muscle. Biochem J 232: 273-276.

7. Strout HV, Vicario PP, Biswas C, Saperstein R, Brady EJ, Pilch PF, Berger J (1990) Vanadate treatment of streptozocin diabetic rats restores expression of the insulin-responsive glucose transporter in skeletal muscle. Endocrinology 126: 2728-2732.

8. Pugazhenthi S, Khandelwal RL (1990) Insulin-like effects of vanadate on hepatic glycogen metabolism in nondiabetic and streptozocin-induced diabetic rats. Diabetes 39: 821-827.

9. Heyliger CE, Tashiliani AG, McNeill JH (1985) Effect of vanadate on elevated blood glucose and depressed cardiac performance of diabetic rats. Sci- 
ence 227: 1474-1477.

10. Gil J, Miralpeix M, Carreras J, Bartrons R (1989) Insulin-like effects of vanadate on glucokinase activity and fructose 2,6-bisphosphatase levels in the liver of diabetic rats. J Biol Chem 263: 1868-1871.

11. Gomez-Foix AM, Rodriguez-Gil JE, Fillat C, Guinovart JJ, Bosch F (1988) Vanadate raises fructose 2,6-bisphosphate concentrations and activates glycolysis in rat hepatocytes. Biochem J 255: 507512.

12. Pilkis SJ, EI-Maghrabi MR, Claus TH (1990) Fructose 2,6-bisphosphate in control of hepatic gluconeogenesis. Diabetes Care 13: 582-599.

13. Claus TH, EI-Maghrabi MR, Regen DM, Stewart HB, McGrane M, Kountz PD, Nyfeler F, Pilkis J, Pilkis SJ (1984) The role of fructose 2,6-bisphosphate in the regulation of carbohydrate metabolism. Curr Top Cell Regul 23: 57-86.

14. EI-Maghrabi MR, Claus TH, Pilkis J, Pilkis SJ (1982) Regulation of 6-phosphofructo-2-kinase activity by cyclic AMP-dependent phosphorylation. Proc Natl Acad Sci USA 79: 315-319.

15. Sakakibara R, Kitajima S, and Uyeda K (1983) Differences in kinetic properties of phospho and dephospho forms of fructose-6-phosphate, 2-kinase and fructose 2,6-bisphosphatase. J Biol Chem 259: 41-46.

16. Jeannet F, Jeanrenaud B (1990) Insulin activates 6phosphofructo-2-kinase and pyruvate kinase in the liver. J Biol Chem 265: 7202-7206.

17. Colosia AD, Marker AK, Lange AJ, EI-Maghrabi MR, Granner DK, Tauler A, Pilkis J, Pilkis SJ (1988) Induction of rat liver 6-phosphofructo-2-kinase / fructose-2,6-bisphosphatase mRNA by refeeding and insulin. J Biol Chem 263: 18669-18677.

18. Crepin KM, Darville MI, Hue L, Rousseau GG (1988) Starvation or diabetes decreases the content but not the mRNA of 6-phosphofructo-2-kinase in rat liver. FEBS Lett 227: 136-140.

19. Miralpeix M, Katz N, Bartrons R (1990) Effects of vanadate on 6-phosphofructo 2-kinase activity and fructose 2,6-bisphosphate levels in cultured hepatocytes. Cell Biochem Func 8: 237-241.

20. Rider MH, Bartrons R, Hue L (1990) Vanadate inhibits liver fructose-2,6-bisphosphatase. Eur J Biochem 190: 53-56.

21. Colosia AD, Lively M, EI-Maghrabi MR, Pilkis SJ (1987) Isolation of a cDNA clone for rat liver 6phosphofructo-2-kinase/fructose-2,6-bisphosphatase. Biochem Biophys Res Commun 143: 10921098.

22. EI-Maghrabi MR, Claus TH, Pilkis J, Pilkis SJ (1981) Partial purification of a rat liver enzyme that catalyzes the formation of fructose 2,6-bisphosphate. Biochem Biophys Res Commun 101: 1071-1077.
23. Chirgwin JM, Przybyla A, McDonald RJ, Rutter WJ (1979) Isolation of biologically active ribonucleic acid from sources enriched in ribonuclease. Biochemistry 18: 5294-5299.

24. Marglin A, Merrifield RB (1970) Chemical synthesis of peptide and protein. Ann Rev Biochem 39: 841-866.

25. Lowry $\mathrm{OH}$, Rosebrough NJ, Farr AJ, Randall RJ (1951) Protein measurement with the folin phenol reagent. J Biol Chem 193: 265-275.

26. Cifuentes ME, Espinet C, Lange AJ, Pilkis SJ, Hod Y (1991) Hormonal control of 6-phosphofructo-2kinase /fructose-2,6-bisphosphatase gene expression in rat hepatoma cells. J Biol Chem 266: 15571563.

27. Bernier M, Laird DM, Lane MD (1988) Effect of vanadate on the cellular accumulation of pp15, an apparent product of insulin receptor tyrosine kinase action. J Biol Chem 263: 13525-13534.

28. Cordera R, Andraghetti G, DeFronzo RA, Rossetti $L$ (1990) Effect of in vivo vanadate treatment on insulin receptor tyrosine kinase activity in partially pancreatectomized diabetic animals. Endocrinology 126: 2177-2183.

29. Green A (1986) The insulin-like effect of sodium vanadate on adipocyte glucose transport is mediated at a post insulin-receptor level. Biochem J 238: 663-669.

30. Strout HV, Vicario PP, Saperstein R, Slater EE (1989) The insulin-mimetic effect of vanadate is not correlated with insulin receptor tyrosine kinase activity nor phosphorylation in mouse diaphragm in vivo. Endocrinology 124: 1918-1924.

31. Pederson RA, Ramanadham S, Buchan AMJ, McNeill JH (1989) Long-term effects of vanadyl treatment on streptozotocin-induced diabetes in rats. Diabetes 38: 1390-1395.

32. Cam MC, Pederson RA, Brownsey RW, McNeill JH (1993) Long-term effectiveness of oral vanadyl sulphate in streptozotocin-diabetic rats. Diabetologia 36: 218-224.

33. Kaku K, Matsuda M, Matsutani A, Kaneko T (1986) Effect of tolbutamide on fructose-6-phosphate, 2kinase and fructose-2,6-bisphosphatase in rat liver. Biochem Biophys Res Commun 139: 687-692.

34. Matsutani A, Kaku K, Kaneko T (1984) Tolbutamide stimulates fructose-2,6-bisphosphate formation in perfused rat liver. Diabetes 33: 495498.

35. Aoki M, Kaku K, Inoue H, Matsutani A, Kaneko T (1992) Tolbutamide inhibits cAMP-dependent phosphorylation of liver 6-phosphofructo-2-kinase/fructose-2,6-bisphosphatase. Diabetes 41: 334338. 